\title{
Garnet as a monitor for melt-rock interaction: Textural, mineralogical, and compositional evidence of partial melting and melt-driven metasomatism
}

\author{
DR. PHILIPPE GONCALVES ${ }^{1}$, TOM RAIMONDO ${ }^{2}$, JEAN- \\ LOUIS PAQUETTE ${ }^{3}$ AND JAILMA SANTOS DE SOUZA DE \\ OLIVEIRA $^{4}$ \\ ${ }^{1}$ Université de Bourgogne Franche-Comté \\ ${ }^{2}$ University of South Australia \\ ${ }^{3}$ Université Clermont-Auvergne \\ ${ }^{4}$ Universidade Federal da Bahi \\ Presenting Author: philippe.goncalves@univ-fcomte.fr
}

Exhumed migmatites preserve a wealth of information that can be used to decipher the thermomechanical behavior of orogenic continental crust. Migmatites are subject to redistribution of the highly mobile melt component from grain- to crustal scales. Therefore, phase relation modeling requires the consideration of not only changes in environmental variables but also the variation of the equilibrium volume and composition of the system. Garnet has the ability to preserve zoning of divalent cations that reflect changing in these P-T-X variables. To retrieve the maximum information related to garnet chemical evolution, the characterization of major element zoning can be complemented with trace elements that are more resistant to diffusional modification.

In this contribution, we report the integrated petrological and geochemical characterization of a high-grade rock that preserves evidence of changes in $\mathrm{P}-\mathrm{T}$ conditions, partial melting, and melt-driven metasomatism. The selected sample, from the São Francisco craton in Brazil (Salvador) is a layered composite rock that consists of (a) a garnet-bearing quartz-saturated host granulite; (b) a quartzofeldspathic leucosome and (c) a quartz-poor garnet-bearing selvedge.

Petrological analysis and thermodynamic modeling (using $\mathrm{P}-\mathrm{T}-\mu-\mathrm{X}$ phase diagrams) shows that the distinct mineralogy of the selvedge is the result of opposed senses of diffusional mass transfer driven by chemical potential gradients established between the host granulite and the segregated melt during decompression. $\mathrm{H}_{2} \mathrm{O}, \mathrm{CaO}, \mathrm{K}_{2} \mathrm{O}$ and $\mathrm{Na}_{2} \mathrm{O}$ diffused from the melt into the host residue, whereas $\mathrm{SiO}_{2}$ was transferred from the host granulite into the adjacent leucosome.

Compositional maps of garnet shows that they preserve their initial growth zoning in $\mathrm{Ca}$ and trace elements obtianed duringduring prograde partial melting $\left(\sim 0.8 \mathrm{GPa}, 790^{\circ} \mathrm{C}\right)$ and rayleigh fractionation. However, this growth zoning was later modified by intragranular diffusion during decompression and melt-driven metasomatism. We conclude that misleading thermobarometric results and tectonic interpretations would be obtained if the core composition was used to fingerprint the early garnet nucleation stage. This study demonstrates that at high temperature $\left(>750^{\circ} \mathrm{C}\right)$ and in the presence of melt, REE are not less vulnerable to diffusive resetting than divalent cations. 